\title{
Prolonged survival in patients with resected non-small cell lung cancer and single-level N2 disease
}

\author{
Steven M. Keller, MD, ${ }^{a}$ Mark G. Vangel, PhD, ${ }^{\mathrm{b}}$ Henry Wagner, $\mathrm{MD},{ }^{\mathrm{c}}$ Joan H. Schiller, MD, ${ }^{\mathrm{d}}$ Arnold Herskovic, MD, \\ Ritsuko Komaki, MD, ${ }^{f}$ Randolph S. Marks, MD, ${ }^{g}$ Michael C. Perry, MD, ${ }^{\text {h }}$ Robert B. Livingston, MD, ${ }^{i}$ and \\ David H. Johnson, MD, for the Eastern Cooperative Oncology Group
}

\begin{abstract}
From the Departments of Cardiothoracic Surgery, Montefiore Medical Center, ${ }^{\mathrm{a}}$ Bronx, NY; Biostatistics, Dana Farber Cancer Institute, ${ }^{\mathrm{b}}$ Boston, Mass; Radiation Oncology, H. Lee Moffitt Cancer Center, ${ }^{\mathrm{c}}$ Tampa, Fla; Medical Oncology, University of Wisconsin, ${ }^{\mathrm{d}}$ Madison, Wis; Radiation Oncology, Oakwood Hospital, ${ }^{\mathrm{e}}$ Detroit, Mich; Radiation Oncology, M.D. Anderson Cancer Center, ${ }^{\mathrm{f}}$ Houston, Tex; Medical Oncology, Mayo Clinic, ${ }^{\mathrm{g}}$ Rochester, Minn; Medical Oncology, University of Missouri, ${ }^{\text {h }}$ Columbia, Mo; Medical Oncology, University of Washington, ${ }^{i}$ Seattle, Wash; Medical Oncology, Vanderbilt University, ${ }^{j}$ Nashville, Tenn.
\end{abstract}

This study was coordinated by the Eastern Cooperative Oncology Group (Robert L. Comis, MD, Chair); participating cooperative groups included the Cancer and Leukemia Group B, the North Central Cancer Treatment Group, the Radiation Therapy Oncology Group, and the Southwest Oncology Group. The contents of this article are solely the responsibility of the authors and do not necessarily represent the official views of the National Cancer Institute.

Supported in part by grants from the Public Health Service (CA23318, CA66636, CA21115, CA14958, CA49957, CA21076, CA73590, CA25224, CA21661, CA20319), the National Cancer Institute, National Institutes of Health, and the Department of Health and Human Services.

Read at the Eighty-third Annual Meeting of The American Association for Thoracic Surgery, Boston, Mass, May 4-7, 2003.

Received for publication May 20, 2003; revisions received Nov 5, 2003; accepted for publication Nov 10, 2003.

Address for reprints: Steven M. Keller, MD, Department of Cardiothoracic Surgery, The Montefiore Medical Center, 3400 Bainbridge Ave, Suite 5B, Bronx, NY 10467 (E-mail: skeller@montefiore.org).

J Thorac Cardiovasc Surg 2004;128:130-7

$0022-5223 / \$ 30.00$

Copyright $\odot 2004$ by The American Association for Thoracic Surgery

doi:10.1016/j.jtcvs.2003.11.061
Objectives: To test the hypothesis that patients with non-small cell lung cancer and single-level N2 metastases constitute a favorable subgroup of patients with mediastinal metastases, we analyzed the results of the Eastern Cooperative Oncology Group 3590 (a randomized prospective trial of adjuvant therapy in patients with resected stages II and IIIa non-small cell lung cancer) by site of primary tumor and pattern of lymph node metastases.

Methods: Accurate staging was ensured by mandating either systematic sampling or complete dissection of the ipsilateral mediastinal lymph nodes. The overall survival of patients with left lung non-small cell lung cancer and metastases in only 1 of lymph node levels 5, 6, or 7 and right lung non-small cell lung cancer with metastases in only 1 of levels 4 or 7 was compared with that of patients with $\mathrm{N} 1$ disease originating in the same lobe.

Results: The median survival of the 172 patients with single-level N2 disease was 35 months (95\% confidence interval: 27-40 months) versus 65 months (95\% confidence interval: $45-84$ months) for the 150 patients with N1 disease (median follow-up 84 months, $P=.01$ ). However, among patients with left upper lobe tumors, survival was not significantly different between patients with N1 disease and patients with single-level N2 disease ( 49 vs 51 months, $P=.63$ ). The median survival of the 71 patients with single-level N2 metastases without concomitant N1 disease (skip metastases) was 59 months (95\% confidence interval: 36-107 months) versus 26 months (95\% confidence interval: 16-36 months) for the 145 patients with both $\mathrm{N} 1$ and $\mathrm{N} 2$ metastases $(P=.001)$.

Conclusions: Survival of patients with left upper lobe non-small cell lung cancer and metastases to single-level N2 lymph nodes is not significantly different from that of patients with N1 disease. The presence of isolate N2 skip metastases is associated with improved survival when compared with patients with both N1 and N2 disease. Survival should be reported by the lobe of primary tumor and metastatic pattern to guide future clinical trial development, treatment strategies, and revisions of the TNM staging system.

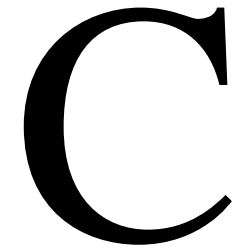
ontroversy continues to surround the role of surgery for patients with non-small cell lung cancer (NSCLC) and metastases to the N2 lymph nodes. Although the clinical course of patients with resected N2 disease has been extensively documented, definitive conclusions regarding the results of treatment are lacking. The continued confusion results from the dissimilar clinical and pathologic categories that comprise $\mathrm{N} 2$ disease.

Numerous factors seem to impact the survival of patients with resected N2 disease. Among them are the manner in which the N2 disease was identified, the performance of mediastinoscopy, the thoroughness of intraoperative lymph node assessment, the location of the lymph node, and the number of nodal levels 
containing tumor. Finally, the fundamental definition of the lymph node level location and boundaries will alter survival.

Intergroup Trial 0115 (Eastern Cooperative Oncology Group 3590), a randomized prospective study of adjuvant therapy after complete resection of stages II and IIIa NSCLC, provided the opportunity to investigate the relation of the number of positive N2 lymph node levels and the pattern of nodal metastases to survival in patients who underwent thorough staging of the mediastinal lymph nodes and received uniform therapy. ${ }^{1}$

\section{Materials and Methods}

The Eastern Cooperative Oncology Group designed a randomized prospective trial of adjuvant therapy to determine whether chemoradiotherapy was superior to radiotherapy alone in preventing local recurrence and prolonging survival in patients with completely resected stages II and IIIa NSCLC. The Radiation Therapy Oncology Group, the North Central Treatment Group, the Cancer and Leukemia Group B, and the Southwest Oncology Group were active participants. The protocol was reviewed and approved by the institutional review board or ethics committee at each site. Written informed consent was obtained from either the patient or his or her surrogate.

Patients who had undergone complete resection of pathologic stages II (T1-2 N1 M0) or IIIa (T1-2 N2 M0, T3 N1-2 M0) NSCLC were eligible for study participation. The International Lung Cancer Staging System accepted by the American Joint Committee on Cancer and the Union Internationale Contre Cancer during the years 1986 to 1997 was used. ${ }^{2}$ Lymph node levels were defined according to the American Thoracic Society. ${ }^{3}$ Level 10 was considered an N1 lymph node.

Complete mediastinal lymph node dissection or systematic sampling was compulsory. The former was defined as resection of all lymph nodes at specified levels, and the latter entailed the removal of a representative lymph node at those same levels. Dissection or sampling of levels 4,7 , and 10 was required during a right thoracotomy and of levels 5 and/or 6 and 7 during a left thoracotomy. To ensure uniform lymph node labeling and staging, each operative note and pathology report was reviewed (S.M.K.).

Mediastinoscopy was required if the preoperative computed tomography (CT) scan demonstrated mediastinal lymph nodes greater than $1.5 \mathrm{~cm}$ in short axis diameter. Patients were ineligible if mediastinoscopy revealed multilevel metastases, contralateral mediastinal disease, or extranodal disease. Patients must have undergone either lobectomy or pneumonectomy. Additional eligibility requirements included a postoperative Eastern Cooperative Oncology Group performance status of 0 or 1 and a postoperative forced expiratory volume 1 sufficient to tolerate the proposed radiotherapy.

Patients randomized to the control arm received 50.4 Gy in 28 daily 1.8-Gy fractions. The initial portion of the treatment was administered with AP-PA portals from $36 \mathrm{~Gy}$ to $42 \mathrm{~Gy}$. The remainder of the treatment was given to the same target volume, but with a lateral/oblique field arrangement that prevented the spinal cord from receiving more than $45 \mathrm{~Gy}$. The treatment arm consisted of identical radiation treatment administered concomi-
TABLE 1. Patient characteristics

\begin{tabular}{lccc}
\hline & N1 (\%) & $\begin{array}{c}\text { Single-level } \\
\text { N2 (\%) }\end{array}$ & $\begin{array}{c}\text { Multiple-level } \\
\text { N2 (\%) }\end{array}$ \\
\hline $\begin{array}{l}\text { Number of patients } \\
\text { Age (median, y) }\end{array}$ & 150 & 172 & 44 \\
$\begin{array}{l}\text { Gender } \\
\quad \text { Male }\end{array}$ & 62.1 & 60.7 & 63.3 \\
$\quad$ Female & $86(57)$ & $98(57)$ & $25(57)$ \\
$\begin{array}{l}\text { Performance status } \\
\quad \text { (fully active) }\end{array}$ & $53(43)$ & $74(43)$ & $19(43)$ \\
$\quad$ 1 (ambulatory) & $97(65)$ & $70(40)$ & $16(36)$ \\
$\begin{array}{l}\text { Treatment } \\
\quad \text { Radiotherapy }\end{array}$ & $68(45)$ & $79(46)$ & $21(48)$ \\
$\quad$ Chemoradiotherapy & $82(55)$ & $93(64)$ & $23(52)$ \\
Histology & & & \\
$\quad$ Squamous & $68(45)$ & $54(31)$ & $15(34)$ \\
$\quad$ Other & $82(55)$ & $118(69)$ & $29(66)$ \\
Lymph node assessment & & & \\
$\quad \begin{array}{l}\text { Systematic sampling } \\
\text { Complete dissection }\end{array}$ & $74(51)$ & $97(56)$ & $13(30)^{*}$ \\
$\quad 76(49)$ & $75(44)$ & $33(70)$
\end{tabular}

${ }^{*} P<.01$.

tantly with VP-16 (120 mg/m ${ }^{2}$ intravenously, days $\left.1-3\right)$ and cisplatin $\left(60 \mathrm{mg} / \mathrm{m}^{2}\right.$ intravenously, day 1$)$. Chemotherapy was initiated within 24 hours of radiotherapy and repeated every 28 days for a total of 4 cycles. The frequency of follow-up physical examinations and type of radiologic studies were not specified.

\section{Statistical Analysis}

Fisher's exact test was used to compare groups with respect to categoric end points (eg, recurrence). ${ }^{4}$ All $P$ values reported from the Fisher's exact test are 2-tailed. Survival time was computed as follows: Patients' deaths are considered as events, and survival time is the time to death from date of registration. Patients who are alive are censored as of last known follow-up.

Survival distributions for survival time was estimated with the Kaplan-Meier method ${ }^{5}$ and compared with the log-rank test. ${ }^{6}$ All $\log$-rank test $P$ values reported are 2-tailed.

\section{Results}

A total of 488 patients were accrued to the study between February 1991 and November 1997 (242 patients to the radiotherapy arm and 246 patients to the chemoradiotherapy arm). The median follow-up was 84 months. The median survival of the 242 patients randomized to the radiotherapy arm was 39 months (95\% confidence interval [CI], 32-50 months), which was not significantly different from the 37-month median survival (95\% CI, 31-43 months) of the 246 patients who received chemoradiotherapy (log rank, $P=.93$ ). A review of the operative and pathology reports revealed that the required intraoperative lymph node assessment had been properly performed and documented in 373 patients. Analysis of this cohort revealed no survival difference between the 2 study arms. ${ }^{1}$ In the absence of an identifiable survival advantage for either treatment arm, the 


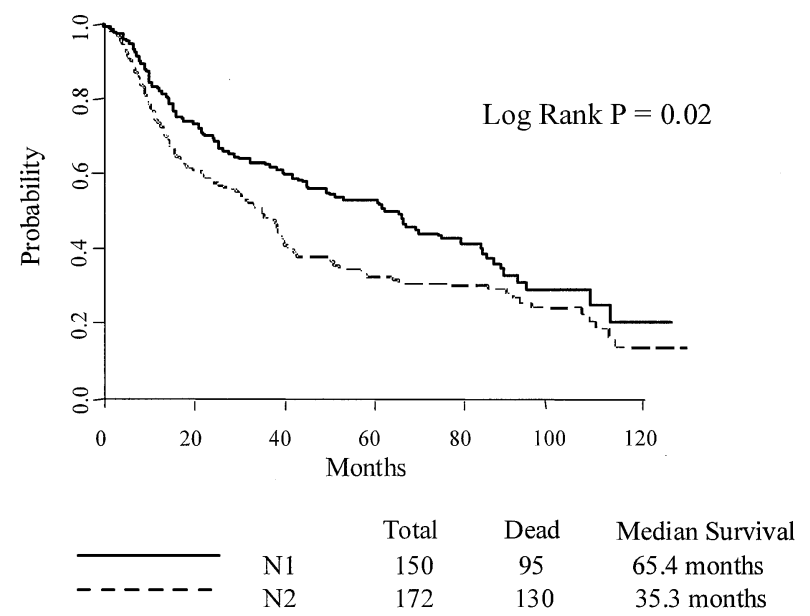

Figure 1. Median survival was 65.4 months (95\% Cl, $45-88.8$ months) for patients with $\mathrm{N} 1$ disease and 30.6 months $(95 \% \mathrm{Cl}$, 22.3-38.6 months) for all patients with N2 disease; 5-year survivals were $52 \%$ and $32 \%$, respectively.

TABLE 2. Comparison of survival by $\mathbf{N}$ status and primary tumor location

\begin{tabular}{lccc}
\hline & $\begin{array}{c}\text { Number of } \\
\text { patients }\end{array}$ & $\begin{array}{c}\text { Median survival } \\
\text { (mo) }\end{array}$ & $\begin{array}{c}\text { Log rank } \\
\boldsymbol{P} \text { value }\end{array}$ \\
\hline Right upper & & & \\
$\quad$ N1 & 47 & 87 & .003 \\
$\quad$ Single-level N2 & 61 & 36 & \\
Right lower & & & \\
$\quad$ N1 & 25 & 45 & .33 \\
$\quad$ Single-level N2 & 34 & 28 & \\
Left upper & & & \\
$\quad$ N1 & 43 & 49 & .63 \\
$\quad$ Single-level N2 & 49 & 51 & \\
Left lower & & & \\
$\quad$ N1 & 28 & 56 & .02 \\
$\quad$ Single-level N2 & 28 & 27 & \\
\hline
\end{tabular}

data of this thoroughly staged group were combined and analyzed by $\mathrm{N}$ status and primary tumor location.

N2 disease was documented in 223 patients, whereas 150 patients had tumors limited to the N1 lymph nodes. The patient demographics appear in Table 1 . The median survival was 65 months (95\% CI, 45-84 months) for the patients with N1 disease and 31 months (95\% CI, 22-39 months) for all patients with $\mathrm{N} 2$ disease (log rank, $P=$ .003). The overall survival of patients with N1 disease was significantly better than that of the 172 patients with tumor limited to a single $\mathrm{N} 2$ station (median 35 months, log rank, $P=.02$ ) (Figure 1). Comparison of survival by $\mathrm{N}$ status and lobe of primary tumor are given in Table 2. Survival of patients with single-level N2 metastases and primary tumors of the left upper lobe was not significantly different from that of patients with N1 disease (Figure 2).

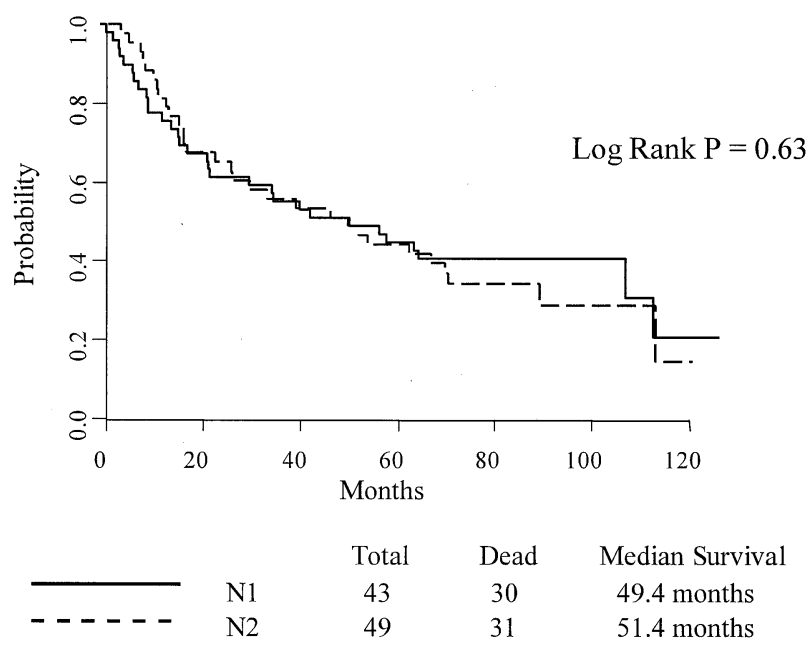

Figure 2. Median survival was 51.4 months (95\% Cl, 22.3 monthsnot reached) for patients with left upper lobe tumors and singlelevel N2 metastases and 49.4 months (95\% Cl, 25.4-89 months) for patients with left upper lobe tumors and N1 disease; 5-year survival was $42 \%$ in both groups.

TABLE 3. Pattern of N2 metastases

\begin{tabular}{ccccc}
\hline & $\begin{array}{c}\text { Right } \\
\text { upper } \\
\text { lobe } \\
(\mathbf{n = 7 8 )}\end{array}$ & $\begin{array}{c}\text { Right } \\
\text { lower } \\
\text { lobe } \\
(\mathbf{n}=\mathbf{4 1})\end{array}$ & $\begin{array}{c}\text { Left } \\
\text { upper } \\
\text { lobe } \\
(\mathbf{n}=\mathbf{5 9})\end{array}$ & $\begin{array}{c}\text { Left } \\
\text { lower } \\
\text { lobe } \\
(\mathbf{n}=\mathbf{3 8})\end{array}$ \\
\hline Node level & & & & \\
2 & 15 & 3 & 1 & 1 \\
4 & 42 & 8 & 5 & 4 \\
5 & $\mathrm{~N} / \mathrm{A}$ & $\mathrm{N} / \mathrm{A}$ & 47 & 11 \\
6 & $\mathrm{~N} / \mathrm{A}$ & $\mathrm{N} / \mathrm{A}$ & 6 & 4 \\
7 & 21 & 34 & 13 & 21 \\
\hline
\end{tabular}

$N / A$, Not available.

Survival of patients with metastases to multiple N2 nodal levels was not significantly different from that of patients with single-level N2 metastases (Figure 3). The pattern of $\mathrm{N} 2$ metastases is shown in Table 3. A comparison of survival by $\mathrm{N}$ status and lobe of primary tumor is given in Table 4 . The survival difference between patients with left upper lobe tumors and single-level N2 disease and patients with left upper lobe tumors and multiple-level N2 disease approached statistical significance (Figure 4). Forty-three of the 49 patients with left upper lobe tumors and single-level $\mathrm{N} 2$ disease had metastases in the level 5 or 6 nodal stations.

Isolated N2 metastases without concomitant N1 disease (skip metastases) were present in 71 patients. Survival of this group was significantly better than that of patients who had both $\mathrm{N} 1$ and $\mathrm{N} 2$ metastases $(P=.001$, Figure 5$)$. The benefit was, however, limited to patients with upper lobe tumors (Table 5). 


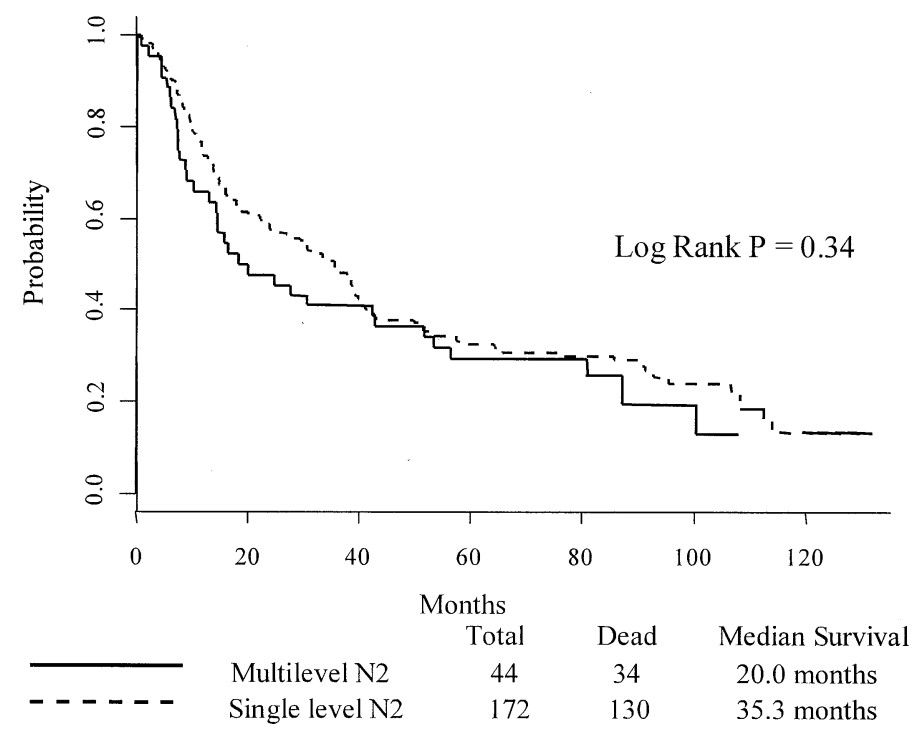

Figure 3. Median survival was 20 months (95\% Cl, 14.3-53.4 months) for patients with multi-level N2 disease and 35.3 months (95\% Cl, 26.9-39.9 months) for patients with single-level N2 disease.

TABLE 4. Survival by number of N2 levels containing tumor

\begin{tabular}{lccc}
\hline & $\begin{array}{c}\text { Number of } \\
\text { patients }\end{array}$ & $\begin{array}{c}\text { Median survival } \\
\text { (mo) }\end{array}$ & $\begin{array}{c}\text { Log rank } \\
\boldsymbol{P} \text { value }\end{array}$ \\
\hline Right upper & & & \\
$\quad$ Single-level N2 & 61 & 35 & .45 \\
$\quad$ Multiple-level N2 & 17 & 100 & \\
Right lower & & & \\
$\quad$ Single-level N2 & 34 & 28 & .46 \\
$\quad$ Multiple-level N2 & 7 & 18 & \\
Left upper & & & \\
$\quad$ Single-level N2 & 49 & 51 & .06 \\
$\quad$ Multiple-level N2 & 10 & 18 & \\
Left lower & & & \\
$\quad$ Single-level N2 & 28 & 27 & .49 \\
Multiple-level N2 & 10 & 15 & \\
\hline
\end{tabular}

\section{Discussion}

Among all the categories of patients with N2 disease, those found to have incidental mediastinal metastases at surgery performed for clinical No disease have the best prognosis. ${ }^{7-13}$ Chest CT measured lymph nodes less than $1 \mathrm{~cm}$ in transverse diameter and, more recently, negative positron emission tomography (PET) scans appear to increase the likelihood of regional rather than systemic disease. The patients included in this study were all treated before the availability of PET scanning but met the then-current definition of clinical N0 disease.

The manner in which the intraoperative assessment of the mediastinal lymph nodes is conducted influences the identification of metastatic lymph nodes and the total number of N2 lymph node levels that contain tumor. ${ }^{14,15}$ Systematic sampling seems as effective as complete mediasti-

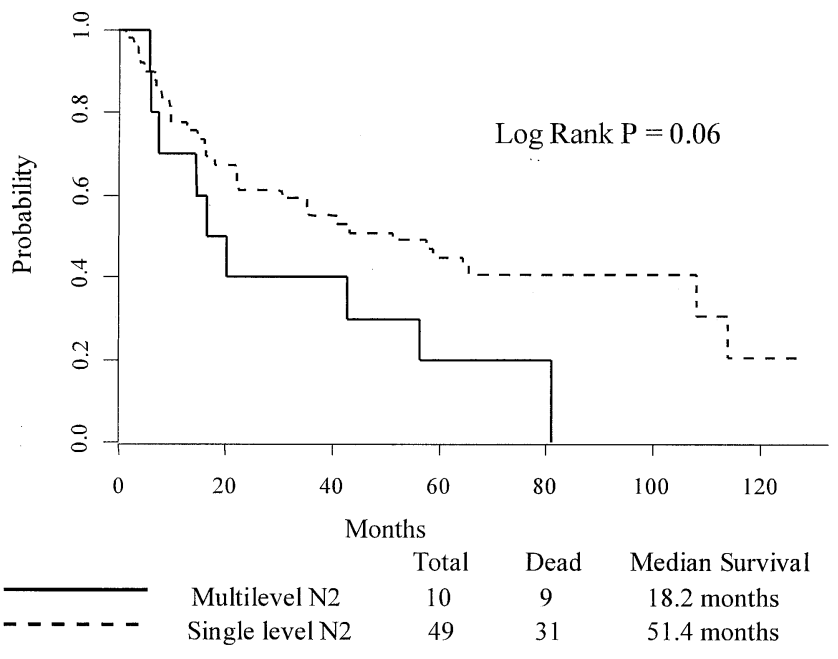

Figure 4. Median survival was 51.4 months (95\% Cl, 22.3 monthsnot reached) for patients with left upper lobe tumors and singlelevel N2 metastases and 18.2 months $(95 \%$ Cl, 7.6 months-not reached) for patients with multiple-level $\mathrm{N} 2$ disease. The difference approximated statistical significance.

nal lymph node dissection in accurately determining the $\mathrm{N}$ status, but complete node dissection identifies more levels of $\mathrm{N} 2$ disease. ${ }^{16}$ Among the 373 patients in the present study cohort, 187 underwent systematic dissection and 186 underwent complete node dissection. N1 disease was identified in $40 \%$ of patients and N2 disease was identified in $60 \%$ of patients who had undergone systematic sampling. This was not significantly different from the $41 \%$ of patients with N1 disease and 59\% of patients with N2 disease found 


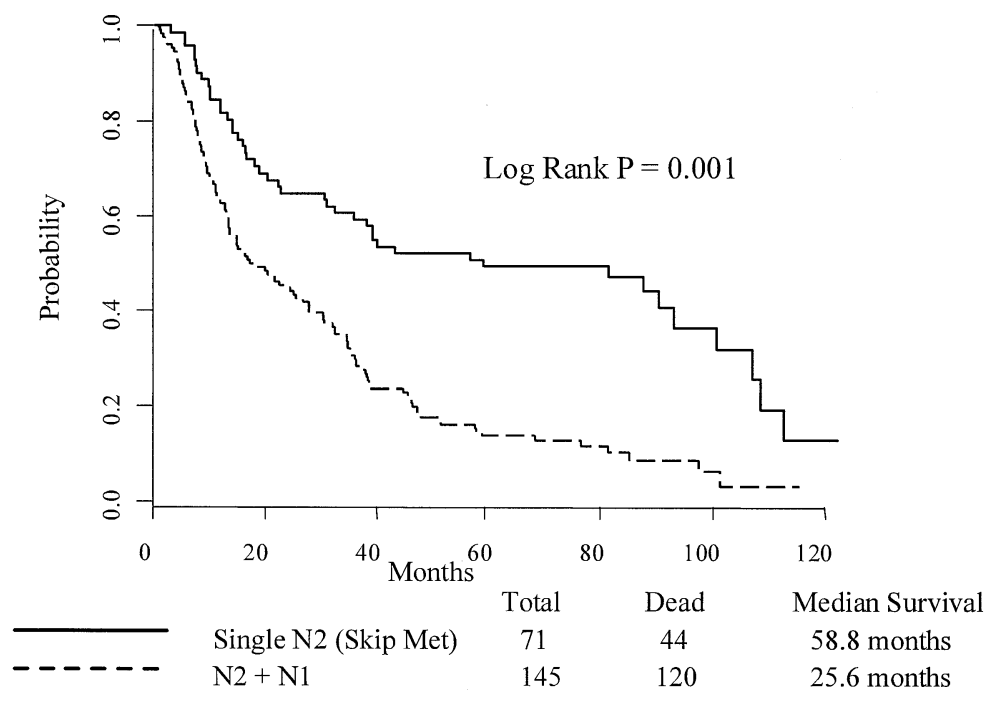

Figure 5. Median survival was 58.8 months (95\% Cl, 35.5-106.7 months) for patients with solitary N2 skip metastases compared with 25.6 months (95\% Cl, $16.2-35.9$ months) for patients with concomitant N1 and N2 disease; 5-year survivals were $50 \%$ and $18 \%$, respectively.

TABLE 5. Survival with skip versus contiguous metastases

\begin{tabular}{lccc}
\hline & $\begin{array}{c}\text { Number of } \\
\text { patients }\end{array}$ & $\begin{array}{c}\text { Median survival } \\
\text { (mo) }\end{array}$ & $\begin{array}{c}\text { Log rank } \\
\boldsymbol{P} \text { value }\end{array}$ \\
\hline $\begin{array}{l}\text { Right upper } \\
\text { Single-level N2 }\end{array}$ & 26 & 93 & \\
$\quad$ N1 + N2 & 52 & 27 & .01 \\
Right lower & & & \\
$\quad$ Single-level N2 & 11 & 39 & .40 \\
$\quad$ N1 + N2 & 30 & 21 & \\
Left upper & & & \\
Single-level N2 & 23 & 81 & .09 \\
$\quad$ N1 + N2 & 36 & 22 & \\
Left lower & & & \\
Single-level N2 & 11 & 13 & .81 \\
N1 + N2 & 27 & 25 & \\
\hline
\end{tabular}

among the 186 patients who underwent complete node dissection. However, among the 222 patients with N2 metastases, multiple levels of $\mathrm{N} 2$ disease were documented in $30 \%$ of patients who underwent complete node dissection and $12 \%$ of patients who had systematic sampling. ${ }^{17}$

The extent of lymph node assessment may also influence survival independently of the staging effect. Two randomized trials have demonstrated improved survival for patients found to have $\mathrm{N} 1$ or $\mathrm{N} 2$ disease who underwent complete node dissection when compared with systematic sampling. ${ }^{16,18}$ Although the current study was not randomized, improved survival was demonstrated for those patients who underwent a complete mediastinal lymph node dissection. ${ }^{17}$ Although one pitfall of the current study is the underidentification of the number of patients with multiple levels of $\mathrm{N} 2$ disease and the different methods used to stage the mediastinum, analysis of the effect of type of nodal assessment by lobe and the number of nodal levels did not change our conclusions.

The number of $\mathrm{N} 2$ levels containing tumor may be inversely related to survival. ${ }^{8-11,19-22}$ Two studies have specifically compared patient survival by the number of involved N2 levels. In both reports, the N2 disease was considered "incidental," discovered at surgery after a chest CT failed to demonstrate enlarged $(>1 \mathrm{~cm})$ mediastinal lymph nodes. Andre and colleagues ${ }^{10}$ documented a median survival of 30 months and a 5-year survival of $34 \%$ for 244 surgical patients with single-station N2 disease compared with a median survival of 16 months and a 5-year survival of $11 \%$ for 78 patients with multilevel N2 disease. Ichinose and colleagues ${ }^{22}$ reported a 5-year survival of $43 \%$ for 209 patients who had not received induction therapy and who were found to have single-level N2 disease, significantly better than the 5-year survival of $17 \%$ for patients with multiple-level N2 disease. Our data do not support the contention that survival of patients with single-level N2 disease is uniformly superior to those with multiple-level N2 disease, but rather it is lobar dependent.

The location of the involved lymph node levels in relation to the primary tumor seems to influence survival. Patients with right upper lobe tumors and metastases to the ipsilateral level 4 lymph nodes have been reported to have improved survival when compared with patients with similar tumors and metastases to the level 7 lymph nodes. ${ }^{23}$ Patients with left upper lobe tumors and metastases to the level 5 or 6 lymph nodes have survival similar to patients with similar T status and N1 disease. ${ }^{24}$ In the current report, we are able to confirm that the survival of patients with left 
upper lobe tumors and single-level N2 disease is similar to that of patients with $\mathrm{N} 1$ disease and superior to that of patients with multiple levels of N2 metastases.

Skip metastases have been attributed to subpleural lymphatics that drain directly to the mediastinum. Numerous investigators have documented improved survival in patients with skip metastases when compared with patients with $\mathrm{N} 1$ and $\mathrm{N} 2$ disease. ${ }^{25-27}$ In this study, the survival advantage was limited to patients with upper lobe tumors, the lymphatic drainage of which is primarily to the paratracheal lymph nodes (right lung tumors) or aortopulmonary window lymph nodes (left lung tumors). The reason for improved survival remains unclear, although patients with skip metastases may have true regional disease that is adequately treated with surgery.

The lymph node definitions and staging system are designed to form homogeneous prognostic patient groups. As more survival data have become available, the definitions have been altered and the staging has been changed. The survival differences among the various patient subgroups with $\mathrm{N} 2$ disease are not adequately reflected in the current definition of N2. The conclusions of this study are based on secondary analysis of data obtained from a randomized trial designed to answer an adjuvant therapy question and must be interpreted as hypothesis-generating rather than definitive. However, we believe that our findings merit consideration in the design of future clinical trials and treatment strategies. Future iterations of the TNM staging system should account for the number of lymph node levels containing metastatic tumor and the metastatic pattern.

\section{References}

1. Keller SM, Adak S, Wagner H, Herskovic A, Komaki R, Brooks BJ, et al. A randomized trial of postoperative adjuvant therapy in patients with completely resected stage II or IIIa non-small-cell lung cancer. $N$ Engl J Med. 2000;343:1217-22.

2. Mountain CF. A new international staging system for lung cancer. Chest. 1986;89(Suppl 4):225S-32S.

3. Tisi GM, Friedman PJ, Peters RM, Pearson G, Carr D, Lee RE, et al. Clinical staging of primary lung cancer. Am Rev Respir Dis. 1983; 127:659-70.

4. Mehta CR, Patel NR. A network algorithm for performing Fisher's exact test in RXC contingency tables. J Am Stat Assoc. 1983;78:42734.

5. Kaplan EL, Meier P. Nonparametric estimation of incomplete observations. J Am Stat Assoc. 1958;53:457-81

6. Mantel N. Evaluation of survival data and two new rank order statistics arising in its consideration. Cancer Chemother Rep. 1966;50:163-70.

7. Shields TW. The significance of ipsilateral mediastinal lymph node metastasis (N2 disease) in non-small cell carcinoma of the lung. J Thorac Cardiovasc Surg. 1990;99:48-53.

8. Vansteenkiste JF, De Leyn PR, Deneffe GJ, Stalpaert G, Nackaerts KL, Lerut TE, et al. Survival and prognostic factors in resected N2 non-small cell lung cancer: a study of 140 cases. Ann Thorac Surg. 1997;63:1441-50.

9. Dalton R, Keller S. Survival following resection of clinically occult N2 non small cell lung cancer. J Cardiovasc Surg. 1994;35(Suppl 1-6): 13-7.

10. Andre F, Grunenwald D, Pignon JP, Dujon A, Pujal JL, Brichon PY, et al. Survival of patients with resected N2 non-small-cell lung cancer: evidence for a subclassification and implications. J Clin Oncol. 2000; 18:2981-9.

11. Goldstraw P, Mannam GC, Kaplan DK, Michail P. Surgical management of non-small-cell lung cancer with ipsilateral mediastinal node metastasis (N2 disease). J Thorac Cardiovasc Surg. 1994;107:19-28.

12. van Klaveren RJ, Festen J, Otten AM, Cox AL, de Graaf R, Lacquet LK. Prognosis of unsuspected but completely resectable N2 non-small cell lung cancer. Ann Thorac Surg. 1993;56:300-4.

13. Martini N, Flehinger BJ, Zaman MB, Beattie EJ Jr. Results of resection in non-oat cell carcinoma of the lung with mediastinal lymph node metastases. Ann Surg. 1983;198:386-97.

14. Gaer JAR, Goldstraw P. Intraoperative assessment of nodal staging at thoracotomy for carcinoma of the bronchus. Eur J Cardiothorac Surg. 1990;4:207-10.

15. Graham ANJ, Chan KJM, Pastorino U, Goldstraw P. Systematic nodal dissection in the intrathoracic staging of patients with non-small cell lung cancer. J Thorac Cardiovasc Surg. 1999;117:246-51.

16. Izbicki JR, Passlick B, Karg O, Bloechle C, Pantel K, Knoefel WT, et al. Impact of radical systematic mediastinal lymphadenectomy on tumor staging in lung cancer. Ann Thorac Surg. 1995;59:209-14.

17. Keller SM, Adak S, Wagner H, Johnson DH. Mediastinal lymph node dissection improves survival in patients with stages II and IIIa nonsmall cell lung cancer. Ann Thorac Surg. 2000;70:358-66.

18. Wu YL, Huang ZF, Wang SY, Yang XN, Ou W. A randomized trial of systematic nodal dissection in resectable non-small cell lung cancer. Lung Cancer. 2003;36:1-6.

19. Sagawa M, Sakurada A, Fujimura S, Sato M, Takahashi S, Usuda K, et al. Five-year survivors with resected pN2 nonsmall cell lung carcinoma. Cancer. 1999;85:864-8.

20. Vansteenkiste JF, De Leyn PR, Deneffe GJ, Lerut TE, Demedts MG. Clinical prognostic factors in surgically treated stage IIIa-N2 nonsmall cell lung cancer: analysis of the literature. Lung Cancer. 1998; 19:3-13.

21. Régnard JF, Magdeleinat P, Azoulay D, Dartevelle P, Deneuville M, Rojas-Miranda A, et al. Results of resection for bronchogenic carcinoma with mediastinal lymph node metastases in selected patients. Eur J Cardiothorac Surg. 1991;5:583-7.

22. Ichinose Y, Kato H, Koike T, Tsuchiya R, Fujisawa T, Shimizu N, et al. Completely resected stage IIIA non-small cell lung cancer: the significance of primary tumor location and N2 station. J Thorac Cardiovasc Surg. 2001;122:803-8.

23. Okada M, Tsubota N, Yoshimura M, Miyamoto Y, Matsuoka H. Prognosis of completely resected pN2 non-small cell lung carcinomas: what is the significant node that affects survival? J Thorac Cardiovasc Surg. 1999;118:270-5.

24. Patterson GA, Piazza D, Pearson FG, Todd TRJ, Ginsberg RJ, Goldberg M, et al. Significance of metastatic disease in subaortic lymph nodes. Ann Thorac Surg. 1987;43:155-9.

25. Yoshino I, Yokoyama H, Yano T, Ueda T, Takai E, Mizutani K, et al. Skip metastases to the mediastinal lymph nodes in non-small cell lung cancer. Ann Thorac Surg. 1996;62:1021-5.

26. Okada M, Tsubota N, Yoshimura M, Miyamoto Y. Proposal for reasonable mediastinal lymphadenectomy in bronchogenic carcinomas: role of subcarinal nodes in selective dissection. J Thorac Cardiovasc Surg. 1998;116:949-53.

27. Bonner JA, Garces YI, Sawyer TE, Gould PM, Foote RL, Deschamps $\mathrm{C}$, et al. Frequency of noncontiguous lymph node involvement in patients with resectable nonsmall cell lung carcinoma. Cancer. 1999; $86: 1159-64$.

\section{Discussion}

Dr Garrett L. Walsh (Houston, Tex). The appropriate management of patients with lung cancer with mediastinal disease remains a complex and often confusing clinical problem for thoracic surgeons. The wide spectrum of $\mathrm{N} 2$ disease can be appreciated in 2 types of patients: One with bulky, multilevel involvement that is clearly evident on a plain chest radiograph, frequently with a fixed mediastinum on palpation at mediastinoscopy; the other with a clinical stage I or II presentation with a normal chest radiograph 
and CT scan with a negative PET scan and normal-appearing, easily removable, mobile nodes seen at surgery but with a small microscopic focus of intranodal, single-station disease appreciated only on final pathology. Both scenarios represent stage III disease.

Dr Keller and his colleagues present a very specific subset of patients with completely resected stage II and stage III disease, with appropriately staged mediastinums, who have already survived their operation to be enrolled in the adjuvant Eastern Cooperative Oncology Group trial. Their analysis demonstrates an improved survival in patients with left upper lobe tumors with singlestation $\mathrm{N} 2$ disease comparable to patients with $\mathrm{N} 1$ disease that may justify reclassifying aortopulmonary window nodes in left upper lobe tumors as N1 disease.

Although this is an important analysis of a randomized trial, the conclusions are not new. Dr Martini pointed out more than 20 years ago that patients with surgically resected single-station N2 disease had an improved prognosis over those with multilevel mediastinal disease. Inferior mediastinal nodes had a worse prognosis over nodes in upper mediastinal locations.

Dr Patterson and the Toronto group at the Society of Thoracic Surgeons meeting in 1986 presented their experience with this specific subset of patients with left upper lobe lesions with positive subaortic lymph nodes. Their 5-year survival with completely resected tumors and single-site $\mathrm{N} 2$ disease was also identical to these data presented today (or $42 \%$ at 5 years).

Why do patients with left upper lobe lesions seem to do better? Many of the patients in Patterson's review and all of the patients in this study received postoperative radiation therapy. Radiation therapy is known to work better in tissues with an intact blood supply. The patients with left upper lobe tumors in these 2 reports would not have undergone sacrifice of the blood supply of the paratracheal nodes as would occur in right-sided procedures with mediastinal dissections of the level 4 nodes. Could the improvement in survival for left upper lobe tumors in fact be a result of an improved radiation therapy response and local control in mediastinal tissues that have not been surgically violated? I would be interested in Dr Keller's thoughts regarding this potential radiation/biology explanation.

Although not described in the article, were there any other characteristics of the primary left upper lobe tumors identified through multivariate analysis that could contribute to the improved survival, such as more favorable histology, smaller tumors, less visceral pleural involvement, or female gender? Were the aortopulmonary window nodes involved separately in all cases or were some positive by direct extension from the left upper lobe lesions? Was there a comparable number of lobectomies and pneumonectomies performed for left upper lobe lesions compared with other sites?

Although your analysis certainly will be helpful during the postoperative discussion with patients when their final pathology is available, how should we apply this knowledge to the patient who will present to our office next week with a left upper lobe primary with a clinically enlarged $1.5-\mathrm{cm}$ aortopulmonary window node? Let us assume that the patient is not hoarse and that his or her PET scan demonstrates uptake only in the primary tumor and the node but no other sites. Would you perform a cervical mediastinoscopy and/or Chamberlain or VATS or FNA for this patient with clinical stage IIIa or simply proceed to left upper lobectomy and medias- tinal node dissection? If a stage III neoadjuvant protocol were available, would this patient be an appropriate candidate or should he or she be excluded on the basis of your survival data?

Although the emphasis has been on the left upper lobe tumors, your table comparing $\mathrm{N} 1$ versus single-level $\mathrm{N} 2$ by primary tumor lobe also shows no significant difference for right lower lobe lesions. Although the median survival in right lower lobe N1 versus single-site N2 is 17 months apart, the statistics would argue that your conclusions in the abstract should also apply to right lower lobe primaries.

Finally, you state that improved survival in these single-station $\mathrm{N} 2$ sites indicates the need to modify the current lung cancer staging system. How would you realistically modify the present staging system to take into account the anatomic or biologic deviations that you have identified and still have a practical and workable system?

Dr Keller. The paratracheal lymph nodes, levels 2 to 4 , in the patients analyzed in this study were less than $1 \mathrm{~cm}$ in diameter and therefore unlikely to contain metastatic tumor. Therefore, I do not believe that the theoretic advantage of radiating cancer-containing tissues with an intact blood supply is a likely explanation for our results.

We found no difference in gender, histology, or surgical procedure in patients who had left upper lobe tumors compared with patients with other tumors. I do not have information regarding the direct extension of tumor to the lymph nodes versus metastases through lymphatic channels.

These data are not directed at the clinical situation that you described, because all patients had mediastinal lymph nodes less than $1 \mathrm{~cm}$ in diameter. However, in my practice, in a patient such as you have described, with a $1.5-\mathrm{cm}$ lymph node that is PETpositive, I would proceed with surgery and not with other diagnostic procedures.

Our results would certainly have been much neater if the left upper lobe was different from all the other lobes. The reason we chose not to emphasize the right lower lobe was because the difference in the median survival, although not significant, was still very large (17 months). Although Dr Patterson and other authors have demonstrated improved patient survival with resected tumors of the left upper lobe and associated N2 metastases when compared with the other lobes, there were no previously published supporting data regarding improved survival of tumors in the right lower lobe.

The staging system might be modified to take into consideration the location of the primary tumor and the pattern of lymph node metastases. For instance, level 5 or 6 lymph nodes would be considered as N1 lymph nodes for patients with left upper lobe tumors. In addition, stratification by lobe of the primary tumor and the presence or absence of skip metastases may provide useful information in interpreting the results of future adjuvant trials.

Dr Richard H. Feins (Rochester, $N Y$ ). I certainly applaud your continued massaging of the data from this intergroup trial, the only phase III trial for lung cancer that has been reported since the end of the Lung Cancer Study Group.

I would just ask you, from a practical standpoint, what do your data tell you about the conduct of an operation so that one could truly identify which patients have single-station N2 disease and 
therefore would benefit from resection? For example, is it necessary to perform a complete lymph node dissection with frozen sections of all tissue? Is a mediastinoscopy necessary for everybody? Somewhere we have to come up with a strategy whereby the thoracic surgeon can identify the subgroup of patients who are going to have the improved survival.

Dr Keller. These patients were all enrolled in the original study after surgery; therefore I do not have any data regarding the specifics of their preoperative evaluation other than to say that all the mediastinal lymph nodes were less than $1 \mathrm{~cm}$ in size. If the lymph nodes were larger, the protocol mandated mediastinoscopy to demonstrate that tumor was present only at a single nodal level. Analysis of the data clearly demonstrated that systematic sampling at defined lymph node levels stages the patients just as accurately as a complete node dissection. However, a complete node dissection will identify more levels of $\mathrm{N} 2$ disease than a systematic sampling.

Dr David H. Harpole, Jr (Durham, NC). I have a comment and then a question. The comment is that I want those in the audience to realize that this is a very key study and that the authors should be congratulated, because there have been very few large multi-institutional cooperative group studies in which a surgeon has had a very significant role. Dr Keller and his group have done a great job of not only getting this trial designed and finished but also examining surgical issues in respect to the results of the trial as opposed to just the usual medical/oncology issues. So I think we all need to appreciate the hard work that went into this.

Now, putting on my clinical trials hat, I have to remind the audience as well that, unfortunately, although as provocative as these data are (and I think there is some truth in these findings, and it is important to follow up on them), when one does a subset analysis on data sets that were not included in the primary and secondary objectives of a trial, the statisticians will tell you that sometimes the data do not necessarily tell the whole truth. The outcomes from the Z30 American College of Surgeons Oncology Group trial, which looks at the randomization of nodal dissection and sampling, will be able to add more information with respect to these left upper lobe lesions.

\section{Online-www.aats.org}

Now you can get The Journal of Thoracic and Cardiovascular Surgery online. The Journal online brings you faster delivery time, easy searching of current and back issues, links to PubMed, AATS, WTSA, and other important sites, and more. Visit the Journal online today.

\section{Receive tables of contents by e-mail}

To receive the tables of contents by e-mail, sign up through our Web site at http://www.mosby.com/jtcvs

Choose E-mail Notification

Simply type your e-mail address in the box and click the Subscribe button. Alternatively, you may send an e-mail message to majordomo@mosby.com. Leave the subject line blank and type the following as the body of your message: subscribe jtcvs_toc

You will receive an e-mail to confirm that you have been added to the mailing list.

Note that TOC e-mails will be sent out when a new issue is posted to the Web site. 